\title{
TRAJECTORIES OF PLANT RECOVERY IN BLOCK-CUT PEATLANDS 35 YEARS AFTER PEAT EXTRACTION
}

\author{
GONZÁLEZ, E.* - ROCHEFORT, L. - POULIN, M. \\ Peatland Ecology Research Group and Centre d'Études Nordiques, \\ 2425, rue de l'Agriculture, Université Laval, Québec, Québec, G1V 0A6, Canada \\ (phone: +1 4186562131 ext. 7058, fax: +1418656 7856) \\ *Corresponding author \\ e-mail:eduardo.gonzalez-sargas.1@ulaval.ca; edusargas@hotmail.com \\ (Received $8^{\text {th }}$ January 2013; accepted $28^{\text {th }}$ October 2013)
}

\begin{abstract}
The initial question of any ecological restoration project should be whether the degraded ecosystem may recover spontaneously in a reasonable time period or active intervention is needed. We examined the successional trajectories of vegetation within peatlands exploited by the traditional blockcut technique in Eastern Canada, with the final purpose of identifying sites which need human intervention to ensure the return of a typical Sphagnum-dominated bog community that accumulates C. Ordinations showed that the development of vegetation was different between three block-cut peatland regions. Peatlands of one of the regions were initially colonized by tall, dense ericaceous shrubs. There, communities tended to become increasingly dominated by trees and understories were closing over time, therefore not being on a trajectory toward the recovery of a Sphagnum-dominated system that accumulates peat in the future. Intervention is therefore recommended, for example by blocking still active drainage ditches. In the peatlands of the other two regions, Sphagnum had a high initial cover and remained dominant ten years later. However, species typically found in hummocks gained relative importance vs. those associated to hollows. More time is needed to decide whether these sites could be left unmanaged as they have remained after their abandonment 35 years ago.
\end{abstract}

Keywords: abandoned exploited bogs, cutover peatlands, partial tb-PCA, spontaneous revegetation, mire

\section{Introduction}

Peatlands are severely disturbed by peat extraction for fuel and horticultural purposes, which causes drastic and sometimes irreversible changes in their structure and functioning (Smart et al., 1986; Lavoie and Rochefort, 1996; Rowlands and Feehan, 2000; Girard et al., 2002). Once abandoned, cutover bogs are minimally recolonized by plants because they are left with harsh environmental conditions such as altered hydrology (Price et al., 2003; Price and Whitehead, 2004), surface instability caused by wind, water erosion and frost heaving (Campbell et al., 2002; Groeneveld and Rochefort, 2002), as well as residual peat surfaces with unsuitable physical properties (Price and Whitehead, 2001). However, some plant species are able to colonize abandoned peat fields, especially those where peat was extracted manually using the block-cut method (Girard et al., 2002).

Traditionally, block-cut peat extraction was undertaken by hundreds of workers with shovels, leaving a topography characterized by alternating baulks and trenches (Rochefort, 2001). Unlike modern milling and vacuum techniques, the absence of heavy machinery in block-cut extraction required less intense drainage activities and did not compact soil, in turn resulting in conditions more favorable for plant recolonization (Soro et al., 1999; Price and Whitehead, 2001; van Seters and Price, 2001; Lavoie et al., 2003; Poulin et al., 2005; Konvalinkova and Prach, 2010). As well, plant fragments 
were left behind in peat extracted trenches, further promoting natural revegetation. Still, despite effective spontaneous recolonization in block-cut peatlands, species composition and cover differ notably from that found in undisturbed peatlands (Konvalinkova and Prach, 2010), even many decades after abandonment (Soro et al., 1999). Block-cut sites are mostly recolonized by vascular plants, but the cover of the characteristic Sphagnum mosses typical of natural ombrotrophic peatlands may vary considerably (Poulin et al., 2005).

The development of Sphagnum carpets is essential for restoring the ecological function of carbon accumulation in bogs (Rochefort, 2000). In the restoration context of Eastern Canada, the short-term goal for cut-over peatlands is to re-establish a plant cover composed of peat bog species dominated by Sphagnum, which favours the recovery of the acrotelm and peat accumulation in the long term (Rochefort et al., 2003). Restoring this ecological service thus represents an "objective-based" strategy in the sense that it does not aim to return to pristine, undisturbed conditions of reference sites but rather focuses on the return of ecosystem functionality, a well-accepted goal by the society at least for irreversibly disturbed sites such as mined peatlands (objectivebased restoration, sensu Dufour and Piégay, 2009; intervention ecology, sensu Hobbs et al., 2011). Knowing more about the fate of such disturbed peatlands is also important for conservation of regional biodiversity. For example, block-cut sites are usually located near current industrial sites. As has been shown to be the case for natural peatland remnants (Poulin et al., 1999; Delage et al., 2000), block-cut sites could potentially play a role in preserving animal and plant populations locally. They could also be a source of plant diaspores during or after restoration work on sites currently abandoned after mechanized peat extraction (see moss transfer layer restoration technique described in Rochefort et al., 2003).

Development of plant communities in block-cut peatlands, that is, how the trajectories of plant communities evolve after initial establishment, has been even less frequently studied than plant colonization. Assessments using space-for-time substitutions have been applied to block-cut studies occasionally (Konvalinkova and Prach, 2010), but they yield less reliable information than monitoring using permanent plots. Yet, the latter is logistically difficult to implement and therefore infrequent in ecological studies. To our knowledge, there has been no long-term monitoring study of block-cut peatlands left to revegetate spontaneously, particularly on a broad regional scale. As restoration is fundamentally the manipulation of communities towards a desired trajectory, a better knowledge of spontaneous recolonization patterns would provide a reference framework for undertaking restoration action and predict management outcomes (Walker et al., 2007). A fundamental question in the science of ecological restoration is whether we can rely upon spontaneous succession (passive restoration) to restore a disturbed ecosystem or active intervention is needed (Prach and Hobbs, 2008).

In the mid-1990s, a large-scale survey of cutover peatlands, including block-cut sites, was conducted in Eastern Canada (Poulin et al., 2005), one of the primary horticultural peat-producing regions of the world (Warner and Buteau, 2002). At that time, sites had been abandoned for $\sim 25$ years and were already at least partly revegetated. We revisited the same block-cut sites ten years later, in 2005-2006 ( $\sim 35$ years after abandonment), to evaluate whether their plant communities were on a trajectory towards the recovery of a Sphagnum-dominated system typical of bogs. By answering this question, our ultimate objective was to evaluate whether these sites were self-regenerating or instead active 
intervention was needed to ensure the restoration of the key ecological functions of peat accumulation and preservation of regional biodiversity.

\section{Materials and methods}

\section{Study sites}

The study was carried out in three industrial peatland regions covering a biogeographic gradient from Atlantic to Inland areas in the Eastern Canadian provinces of New Brunswick and Québec (Fig. 1). A total of 6800 ha (New Brunswick) and 6000 ha (Québec) of peatland has been mined in these provinces, representing 5\% and $0.05 \%$ of their total peatland area, respectively (Poulin et al., 2004).

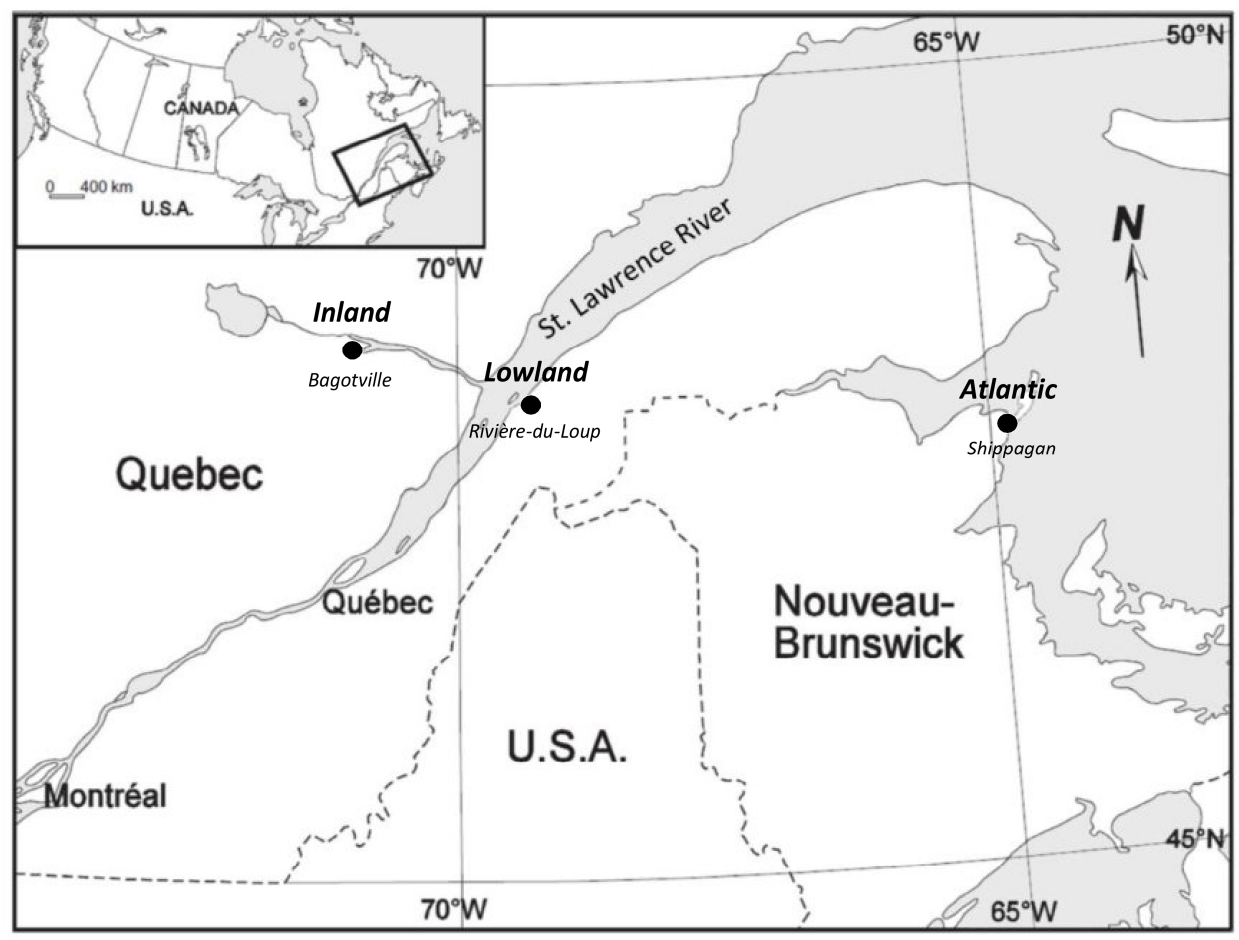

Figure 1. Location of the three abandoned block-cut mined peatland regions in the Eastern Canadian provinces of Québec and New Brunswick. The regions corresponding to major Canadian climatic regions: Atlantic region: Mean annual temperature $=4.5^{\circ} \mathrm{C}$, Total annual precipitation $=1059 \mathrm{~mm}$, Precipitation as snow $=318 \mathrm{~mm}$. Lowland of Great Lakes /St. Lawrence region: Mean annual temperature $=3.2{ }^{\circ} \mathrm{C}$, Total annual precipitation $=963 \mathrm{~mm}$, Precipitation as snow $=270 \mathrm{~mm}$. Inland of Northeastern Forest region: Mean annual temperature $=2.3{ }^{\circ} \mathrm{C}$, Total annual precipitation $=887 \mathrm{~mm}$, Precipitation as snow $=296 \mathrm{~mm}$ (Environment Canada, 2012)

Most of the studied peatlands developed in lowlands of sand, silt, and clay marine deposits. Classified as Atlantic boreal peatlands and Maritime Atlantic boreal peatlands, they are primarily rainfed (ombrotrophic bogs; National Wetlands Working Group 1988). The peatlands are concentrated in three main regions, corresponding to major Canadian climatic regions: Atlantic (Atlantic Canada region), Lowland (Great Lakes / 
St. Lawrence region) and Inland (Northeastern Forest region). The Atlantic peatland region included two peatlands near the coastal villages of Inkerman Ferry and Shippagan, located $\sim 10 \mathrm{~km}$ apart in the province of New Brunswick (Fig. 1). The Lowland peatland region was one of the biggest peat production regions in southern Québec and included the six peatlands of Isle Verte, Coteau-du-Tuff, Saint Arsene, Cacouna, Le Parc and Saint Laurent, all located within a $\sim 20 \mathrm{~km}$ belt along the south shore of the St. Lawrence River near the town of Rivière-du-Loup (Fig. 1, for a more detailed description of this peatland region, the Bas-Saint-Laurent, see Pellerin and Lavoie, 2000; 2003). Peat extraction activities were especially intense in the 1940s and 1950s along the south shore of the St. Lawrence River, particularly in the vicinity of Rivière-du-Loup, resulting in a historically higher concentration of cutover peatlands in the area. The Inland region included the only one extensive traditionally block-cut peatland that was not re-opened for vacuum harvesting and still remained abandoned, located in the proximity of Bagotville (Fig. 1). A summary of the characteristics of the nine abandoned bogs in the three peatland regions is provided in Table 1. Although the traditional block-cut method severely disturbed the ecosystem, note that the method left in place a peat body of at least $1 \mathrm{~m}$ in depth after exploitation, preserving ombrotrophic conditions in all sites and making the spontaneous return of Sphagnum a feasible expectation. The $\mathrm{pH}$ in residual peat ranged within the typical values for natural bogs (2.9 - 3.2) of the area reported by Andersen et al. (2011) and only EC was slightly higher (40 and $9 \mu \mathrm{S} \mathrm{cm}^{-1}$ in the Lowland and Inland regions respectively, Andersen et al., 2011; no data available for the Atlantic region).

The three peatland regions comprise all of Eastern Canada's abandoned block-cut peatlands. They were totally or partially exploited by the block-cut method before being abandoned to spontaneous revegetation. The first step of the block-cut method involves digging out a network of primary drainage ditches to divide the natural peatland into rectangular sectors and lower the water table level. A first row of peat is then extracted, after removing and setting aside the live surface vegetation. Peat blocks are stacked to dry on racks located on adjacent higher surfaces (baulks) as the surface area under exploitation widens (Fig. 2a). The pattern of trenches and baulks resulting from this process remains identifiable decades after abandonment (Fig. 2b). A trench is typically $\sim 10-15 \mathrm{~m}$ wide, and a baulk $\sim 3-4 \mathrm{~m}$ wide. We examined trenches exclusively; we excluded baulks because they are largely devoid of Sphagnum (Poulin et al., 2005) and are unlikely to evolve toward plant communities typical of bogs, at least not until such time as the trenches fill up with accumulated organic matter. 

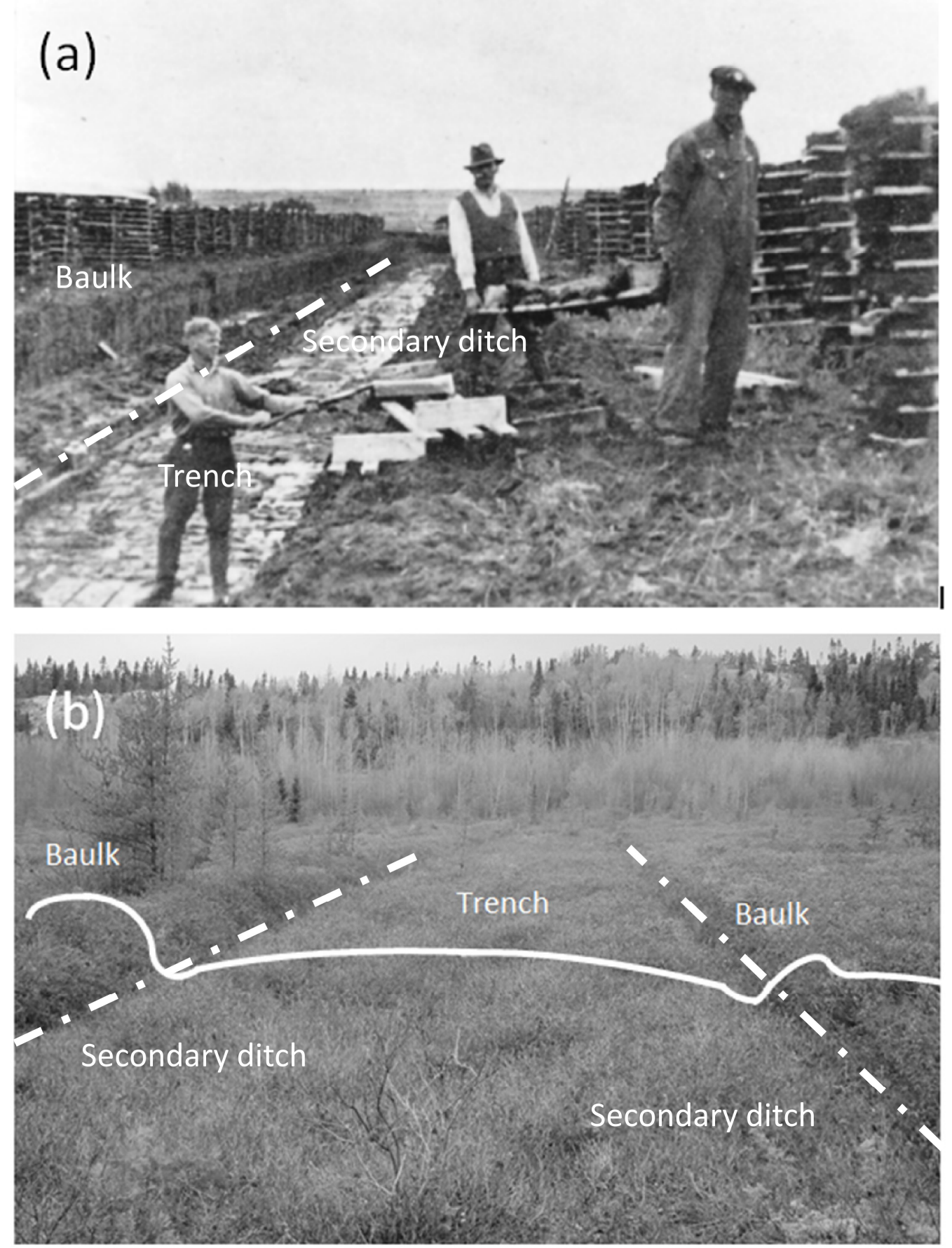

Figure 2. (a) Block-cut exploitation in the Isle Verte peatland (Lowland region) during the 1940s. Workers deposit peat blocks on drying racks (from Risi et al., 1953; courtesy of the Ministère des Ressources Naturelles du Québec); (b) Characteristic topography of alternating baulks and trenches, decades after abandonment and spontaneous recolonization 
Table 1. Summary of the main characteristics of the nine bogs at three peatland regions of Eastern Canada

\begin{tabular}{|c|c|c|c|c|c|c|c|c|c|c|c|}
\hline \multirow[b]{2}{*}{ General characteristics } & \multicolumn{3}{|c|}{ Atlantic } & \multicolumn{7}{|c|}{ Lowland } & \multirow{2}{*}{$\begin{array}{c}\text { Inland } \\
\text { BA }\end{array}$} \\
\hline & IF & SH & Total & IV & CT & $\mathbf{S A}$ & CA & $\mathbf{L P}$ & SL & Total & \\
\hline Number of trenches & 5 & 10 & 15 & 4 & 4 & 5 & 7 & 11 & 24 & 55 & 10 \\
\hline Size of abandoned peatland (ha) & 122 & 189 & - & 89 & 23 & 20 & 71 & 29 & 220 & - & 32 \\
\hline UTM coordinates & $47^{\circ} 42^{\prime} \mathrm{N}$ & $47^{\circ} 44^{\prime} \mathrm{N}$ & - & $48^{\circ} 02^{\prime} \mathrm{N}$ & $47^{\circ} 58^{\prime} \mathrm{N}$ & $47^{\circ} 56^{\prime} \mathrm{N}$ & $47^{\circ} 54^{\prime} \mathrm{N}$ & $47^{\circ} 52^{\prime} \mathrm{N}$ & $47^{\circ} 49^{\prime} \mathrm{N}$ & - & $48^{\circ} 22^{\prime} \mathrm{N}$ \\
\hline & $64^{\circ} 45^{\prime} \mathrm{W}$ & $64^{\circ} 43^{\prime} \mathrm{W}$ & & $\begin{array}{c}69^{\circ} 18^{\prime} \\
\mathrm{W}\end{array}$ & $\begin{array}{c}69^{\circ} 22^{\prime} \\
W\end{array}$ & $69^{\circ} 26^{\prime} \mathrm{W}$ & $69^{\circ} 27^{\prime} \mathrm{W}$ & $69^{\circ} 30^{\prime} \mathrm{W}$ & $69^{\circ} 29^{\prime} \mathrm{W}$ & & $70^{\circ} 57^{\prime} \mathrm{W}$ \\
\hline $\begin{array}{l}\text { Year of abandonment* } \\
\text { Peat properties } \$\end{array}$ & 1977(0) & $1970(0)$ & $1970 \mathrm{a}(7)$ & 1976(0) & 1968(8) & 1974(4) & $1968(20)$ & 1967(13) & 1965(9) & $1968 b(21)$ & $1970 \mathrm{a}(0)$ \\
\hline Depth of residual peat $(\mathrm{cm})$ & $165(67)$ & 163(104) & $165 \mathrm{a}(104)$ & $144(82)$ & 133(78) & 101(55) & 170(43) & $127(160)$ & 182(159) & $160 \mathrm{a}(208)$ & $174 a(48)$ \\
\hline Von Post & $4(3)$ & 3(4) & $3 b(4)$ & $5(3)$ & $6(2)$ & $5(1)$ & $5(2)$ & $4(0)$ & $5(3)$ & $5 a(4)$ & $3 \mathrm{~b}(4)$ \\
\hline $\mathrm{EC}\left(\mu \mathrm{Scm}^{-1}\right)$ & $85(111)$ & $67(133)$ & $71 \mathrm{a}(135)$ & $60(33)$ & $77(22)$ & $60(41)$ & $81(67)$ & $43(215)$ & $78(103)$ & $76 a(216)$ & $36 \mathrm{~b}(49)$ \\
\hline $\begin{array}{l}\mathrm{pH} \\
\text { Hydrology } \dagger\end{array}$ & $3.6(0.9)$ & $3.1(0.7)$ & $3.2 \mathrm{~b}(1.0)$ & $3.9(0.2)$ & $3.8(0.3)$ & $4.0(0.5)$ & $3.5(1.0)$ & $3.9(0.9)$ & $3.7(0.6)$ & $3.7 \mathrm{a}(1.4)$ & $3.9 \mathrm{ab}(2.3)$ \\
\hline Depth of water table $(\mathrm{cm})$ & 11(29) & $22(29)$ & $17 b(29)$ & $7(6)$ & $2(3)$ & $8(5)$ & $26(28)$ & $5(28)$ & $44(102)$ & $25 b(109)$ & $47 \mathrm{a}(18)$ \\
\hline $\begin{array}{l}\text { Depth of former drainage ditch } \\
(\mathrm{cm}) \\
\text { Landscape (ha in } \mathbf{2 k m} \text { radius)§ }\end{array}$ & $-7(10)$ & $-3(23)$ & $-3 b(23)$ & $11(29)$ & $32(21)$ & $30(25)$ & $-9(15)$ & $25(25)$ & $25(36)$ & $25 \mathrm{a}(54)$ & $-6 b(22)$ \\
\hline Agriculture & $26(37)$ & $84(32)$ & $73 b(103)$ & $342(47)$ & $912(28)$ & $318(168)$ & $753(106)$ & $736(145)$ & 199(381) & $344 a(873)$ & $0 \mathrm{c}(0)$ \\
\hline Forest & $77(49)$ & $284(208)$ & $233 b(331)$ & $520(73)$ & 271(20) & $551(125)$ & $229(65)$ & $309(124)$ & $310(161)$ & $309 a(407)$ & $363 a(32)$ \\
\hline Natural & $593(74)$ & $706(175)$ & $675 a(220)$ & $226(76)$ & $6(0)$ & $86(43)$ & 73(13) & 51(1) & $100(169)$ & $70 c(233)$ & $479 b(77)$ \\
\hline Abandoned block-cut peatland & $122(31)$ & $189(14)$ & $189 \mathrm{a}(68)$ & $89(0)$ & $23(0)$ & $20(0)$ & $71(0)$ & $29(0)$ & $208(220)$ & $71 b(233)$ & $32 b(0)$ \\
\hline Abandoned vacuum peatland & $72(104)$ & $0(0)$ & $0 \mathrm{ab}(136)$ & $0(0)$ & $0(0)$ & $7(1)$ & $14(0)$ & $7(0)$ & $34(57)$ & $11 \mathrm{a}(64)$ & $0 \mathrm{~b}(0)$ \\
\hline Exploited vacuum peatland & $7(4)$ & $167(0)$ & $167 \mathrm{a}(161)$ & $0(0)$ & $6(0)$ & $155(1)$ & $0(0)$ & $0(0)$ & $334(353)$ & $155 a(552)$ & $0 \mathrm{~b}(0)$ \\
\hline
\end{tabular}

Numbers are median values for the $n$ trenches at each abandoned bog. Range in parentheses. IF - Inkerman Ferry, SH - Shippagan, IV - Isle Verte, CT - Coteau-duTuff, SA - Saint Arsene, CA - Cacouna, LP - Le Parc, SL - Saint Laurent, BA - Bagotville. *Information on year of abandonment was gathered from horticultural peat companies. $\neq$ Physicochemical properties were analyzed with three peat samples per trench. The depth of residual peat was measured with an iron bar. Peat EC was measured on samples saturated with distillate water (ratio 1:10) and then corrected according to Sjörs (1952). Peat pH was measured using a portable pH meter on the same 1:10 solution. $†$ The depth of the water table was measured in summer 2005. A negative sign implied that the former drainage ditch (Fig. 2) was completely infilled with peat collapsed from the baulks. \$Landscape variables were calculated using ArcGIS 10 on aerial pictures obtained from Google Maps Satellite View, but only the main categories were included in the table to keep them simple. For each variable, letters indicate homogeneous group of peatland regions after MannWhitney tests 


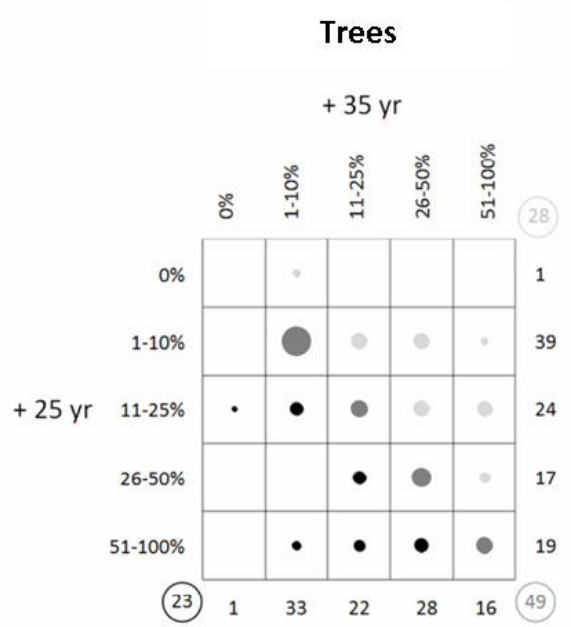

Ericaceous

$+35 \mathrm{yr}$
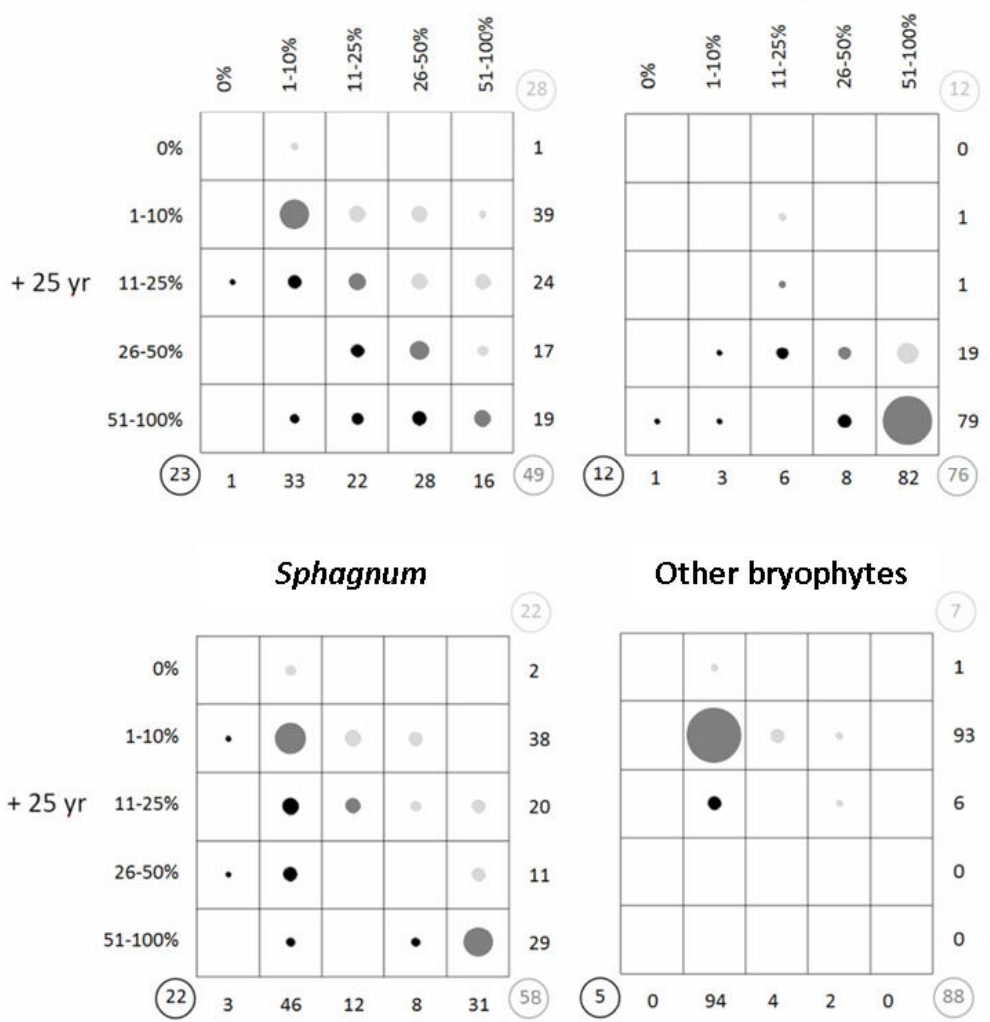

Other bryophytes

(12)

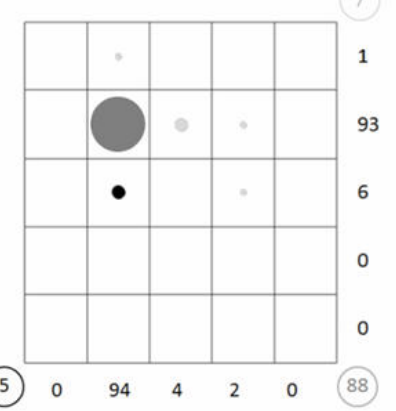

Herbs

$+35 \mathrm{yr}$
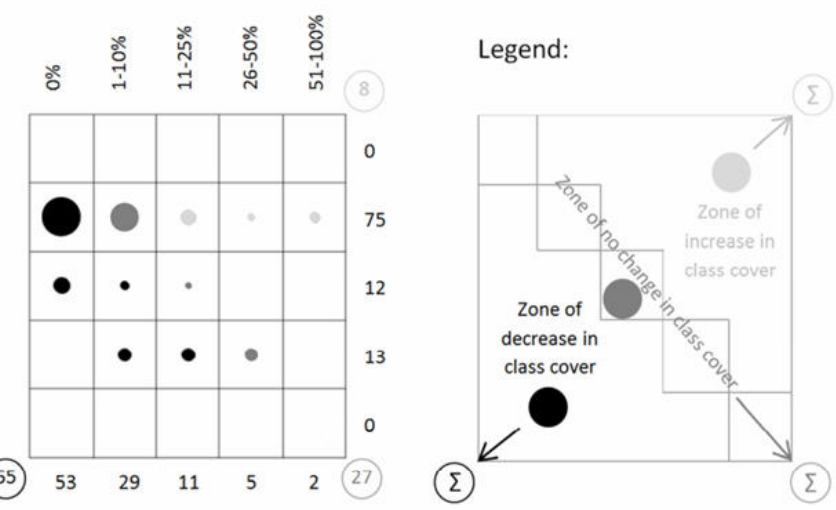

Bare peat

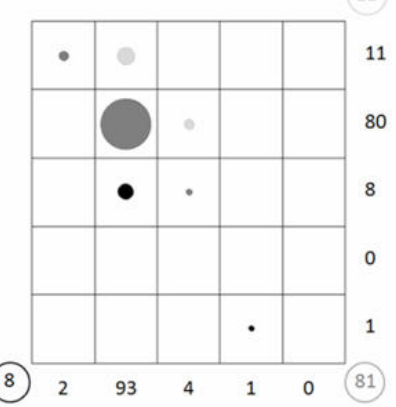

Figure 3. Balloon plots for the cover of six vegetation strata and bare peat in abandoned block-cut peatlands of Eastern Canada. The size of the circles is proportional to the number of trenches $(n=80)$ that were assigned to the cover classes specified in the rows and columns. Column numbers are row sums (frequency of each cover class in 1994-97, 25 yr after abandonment). Row numbers are column sums (frequency of each cover class in 2005-06: $\sim 35$ y after abandonment). Balloon plots were made using the gplots package of $R$ (Warnes, 2011). 


\section{Vegetation surveys}

The exhaustive survey conducted in the 1990s (1994, 1995 and 1997) described the vegetation structure of all trenches in all three peatland regions. This inventory was used to stratify each peatland according to main vegetation structure types and to select representative trenches for species relevés. A total of 2571 trenches were surveyed for vegetation structure, of which 112 were selected for conducting species relevés. Some sectors were reopened for vacuum extraction after the 1990s survey, but we could still revisit 80 of these initial trenches in our 2005-2006 survey (Number of trenches, Table 1).

The same protocol was used for the two surveys. When walking across each trench, the percent cover of six vegetation strata and ground substrate was visually estimated according to the following five percent classes: $0=0 \%, 1=1-10 \%, 2=11-25 \%, 3=26$ $50 \%, 4=51-100 \%$. The strata were described as trees, ericaceous shrubs, herbs, Sphagnum bryophytes, bryophytes other than Sphagnum, lichens and bare peat. Two or more categories could overlap vertically and therefore obtain a value of 4 within the same trench.

For species relevés, the Line-Point Intercept method was used (Bonham, 1989). Ten equidistant transects were established across each trench, such that all plant species including mosses, liverworts, lichens and vascular plants touching a vertical rod were recorded on ten equidistant positions. Species counts over the 100 pinpoints corresponded to the frequency of occurrence of a species within each trench, which we will refer to as "species cover" (as distinct from "species frequency", i.e., the proportion of trenches where the species appeared), even though the Line-Point Intercept method tends to overestimate the cover of some species, such as small ericaceous shrubs (Rochefort et al., in press). Because of taxonomic difficulties in the field, Amelanchier, Cladonia, Carex, Drepanocladus, Lycopodium, Salix and Typha were identified to the genus level only.

The total number of cases of our vegetation (species cover) dataset was therefore 160 (i.e., two surveys $x 80$ trenches). Additionally, in the second survey, the thickness of the new organic matter accumulated since abandonment $(\mathrm{OM})$ was measured at the central point of transects 2,5 and 9 of each trench with a ruler.

\section{Data processing and statistical analyses}

We used partial transformed-based principal component analysis (partial tb-PCA; Legendre and Legendre, 2012) to assess the similarity of plant composition between peatlands as well as their successional trajectories. Before looking at plant composition and trajectories, the effect of time since abandonment was partialled out by running a RDA, for which the year of abandonment was used as the only explanatory variable; a Hellinger's transformation was applied to species cover in order to account for the occurrence of double zeros (Legendre and Gallagher, 2001). Rare species (occurring in less than 5\% of the trenches) were removed from the vegetation matrix before transformation. The significance of the RDA was assessed using a permutation test with 9999 randomized runs (Legendre and Legendre, 2012). A PCA was then carried out on the residuals of the RDA (completing the last step of the partial tb-PCA). The PCA revealed the major community gradients and reflected their temporal evolution (from 25 $\mathrm{yr}$ to $35 \mathrm{yr}$ ). The scores of the trenches on the main axes of the PCA (sites scores, scaling $=1$ ) were then compared between the two surveys using non-parametric 
Wilcoxon matched-pairs tests to assess the degree of community change along the ecological gradients given by the ordination. Finally, the capacity of peatlands to accumulate $\mathrm{OM}$ along the identified ecological gradients was evaluated. The three $\mathrm{OM}$ thickness measurements at each trench were averaged to adjust the best multiple linear function " $\mathrm{OM}=\mathrm{f}(\mathrm{PCA}$ sites scores with scaling 1$)$ ". Only the site scores of the second survey were used, as OM was measured during the second survey only. These steps were carried out for the three peatland regions separately, as preliminary analyses showed a strong regional component in plant composition that drove ordinations when the three regions were analyzed together. Ordinations were carried out using R (version 2.14.0) software ( $R$ Development Core Team, 2011), more precisely the vegan (Oksanen et al., 2011) and ade4 (Dray and Dufour, 2007) packages. SPSS v 13.0 was used to run the univariate non-parametric tests.

\section{Results}

\section{Overview of vegetation strata evolution}

The block-cut peatlands were largely revegetated by the time of the first survey, $\sim 25$ years after exploitation finished. The majority of trenches (79\%) had a cover of ericaceous shrubs higher than $50 \%$, and a great proportion of trenches $(60 \%)$ had been colonized by Sphagnum, with a cover higher than $10 \%$ (Fig. 3). Ten years later, $76 \%$ of the trenches had not experienced any change in ericaceous class cover, which was still by far the dominant plant stratum (Fig. 3). Sphagnum was still very common in 200506, although variability was very high among trenches, both in terms of cover (with two peaks at 1-10 and > 50\%) and development. That is, Sphagnum cover remained stable in only $58 \%$ of the trenches and increased and decreased in the same proportion of trenches (22\%) (Fig. 3). A similar pattern was observed for trees, for which a high variety of situations was observed as well. There was no predominant class cover either in 1994-97 or 2005-06. The main tendency for tree cover, however, was to remain stable (49\%), while increases $(28 \%)$ were slightly more frequent than decreases $(23 \%)$ (Fig. 3). As observed for ericaceous shrubs, cover of bryophytes other than Sphagnum and lichens had changed little ten years after the first survey $(88 \%$ and $81 \%$ of the trenches remained stable, respectively) (Fig. 3). Their cover remained $<10 \%$ in practically all trenches. Finally, herbs and especially bare peat showed a remarkable and generalized decrease in 65 and $82 \%$ of the trenches (Fig. 3).

\section{Development of peatland plant communities}

A total of 119 plant species (Appendix 1) were identified during the two surveys in the 80 trenches of the three peatland regions. For the Atlantic region, the first gradient seemed to represent the vertical zonation of Sphagnum species along hummock-hollow microtopography (PC1, 23\%; Fig. 4a). The hummock species S. fuscum associated with the liverwort Mylia anomala, and the shrub Gaylussacia baccata appeared on the negative side of the gradient. Hollow/lawn associations Eriophorum angustifolium, Sphagnum magellanicum, S. fallax, S. angustifolium dominated the positive side of the gradient. Trenches were alternatively ordinated into a wet to dry gradient (PC2, 16\%; Fig. 5a). Sphagnum spp. and herbs with humid preferences (Rhynchospora alba and Eriophorum angustifolium) had the most negative scores (wet); while ericaceous species, trees and lichens more typical of relatively drier environments appeared on the 
positive end of the gradient (dry). The trajectories of the two Atlantic peatlands diverged over time: Inkerman Ferry became more dominated by plants with wet preference and Shippagan by hummock species (Fig. 4a).

a)

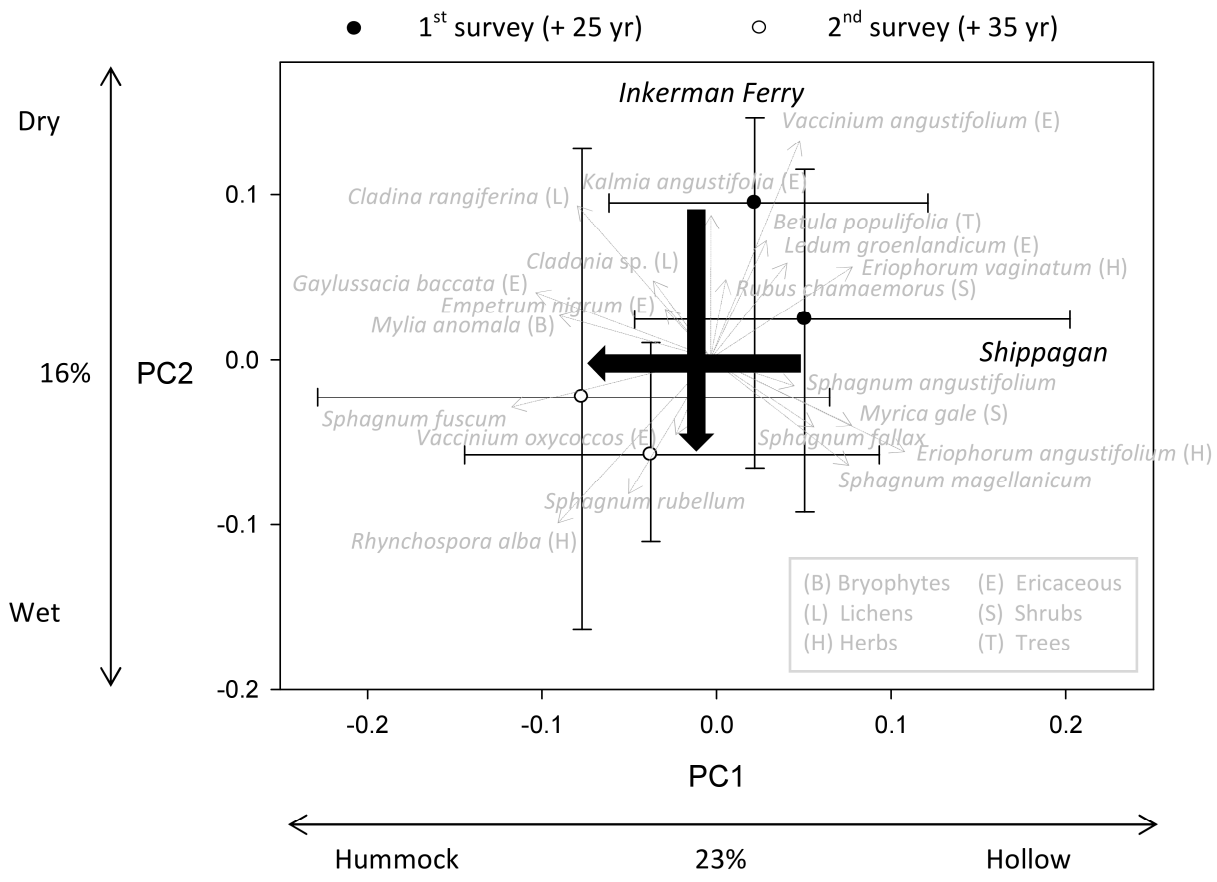

b)

- $\quad 1^{\text {st }}$ survey $(+25 \mathrm{yr}) \quad \circ \quad 2^{\text {nd }}$ survey $(+35 \mathrm{yr})$

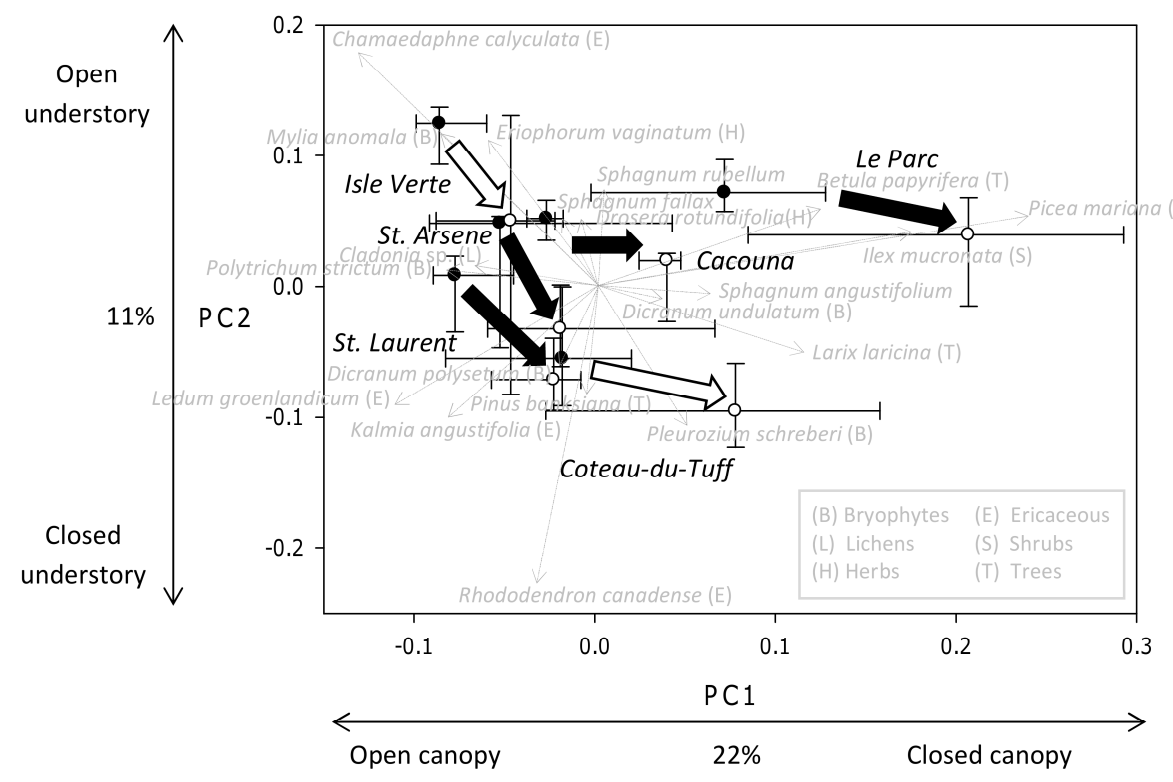


c)

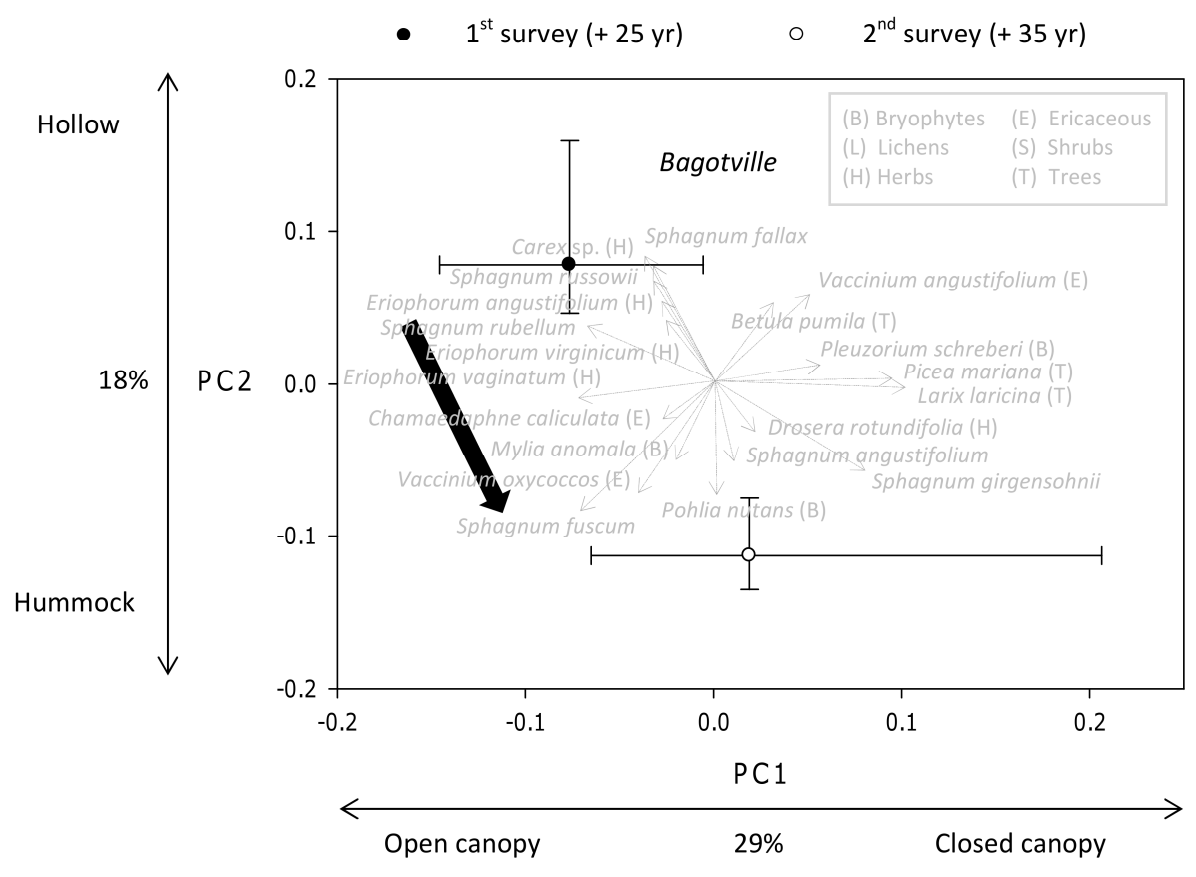

Figure 4. $P C 1$ vs. PC2 biplots of respective partial tb-PCA ordinations (scaling $=1)$ for the plant community at (a) Atlantic, (b) Lowland and (c) Inland abandoned block-cut mined peatlands of Eastern Canada. Plant species cover matrices were built from 30, 110 and 20 cases (two surveys $x$ 15, 55 and 10 trenches, Table 1). To improve visual clarity of the PCA diagram, only the centroids (site scores medians) of each peatland at each one of the two surveys (filled circles $=1994-1997$, open circles $=2005-2006$ ), and the first and third percentile representing the errors, were drawn. Species scores were scaled by multiplying by 1/5 and are represented by dashed grey arrows. Removal of infrequent species resulted in a total of 62 (Atlantic), 55 (Lowland), and 55 (Inland) species for inclusion in the ordination analyses, but only the 20 species with the highest scores are represented at each figure for simplicity. Black arrows indicate that site scores between the two surveys at a given peatland were significantly different (Wilcoxon tests not shown, $P<0.05$ ). Note that if the test was only significant for one of the axes, the arrow was drawn perpendicular to the one with no significance. White arrows were drawn to facilitate identification of the peatlands when the temporal change along the ordination was not significant on either of the two axes. The year of abandonment, whose effect on the vegetation was cancelled out before running the PCA, explained only 9 and 6\% of the vegetation variability among trenches of the Atlantic and Lowland regions, respectively ( $R D A$, permutation test, 9999 runs, $F=2.8017, P=0.004$; and $R D A$, permutation test, 9999 runs, $F=7.0382, P<0.001)$. The RDA was not necessary in the Inland peatland region as it only included one peatland where all trenches were abandoned the same year

The two main gradients detected in the Lowland region reflected light availability (Fig. 4b). An open-closed canopy gradient explained the highest proportion of variability in the plant community (PC1, 22\%), with ericaceous shrubs Chamaedaphne calyculata and Ledum groenlandicum having the most negative scores (open canopy); and with tree species contributing to the closed-canopy side of the gradient. Alternatively, sites were separated along a closed to open understory gradient (PC2, 
11\%). Three ericaceous species forming thick, taller populations (Rhododendron canadense, Kalmia angustifolia and Ledum groenlandicum) had the most negative scores (closed understory), associated with the tree Pinus banksiana and the moss Pleurozium schreberi that typically appears under dense canopies and tolerates shading. Short ericaceous species such as Chamaedaphne calyculata, the herb Eriophorum vaginatum and some bryophytes (Mylia anomala and some Sphagnum spp.) had the most positive scores (open understory). The general tendency of the six peatlands in the Lowland region was to become more closed both in the canopy and understory layers (Fig. 4b).

The Inland region included only one peatland whose trenches were mainly ordinated along an open to closed canopy gradient as well (PC1, 29\%; Fig. 4c). Here, Sphagnum rubellum, S. fuscum and the tussock-forming sedge Eriophorum vaginatum dominated the negative side of the gradient; the trees Picea mariana and Larix laricina; and Sphagnum girgensohnii and Pleurozium schreberi, bryophytes typical of forested peatlands, dominated the positive end of the gradient. Secondly, a hummock-hollow gradient seemed to emerge, as in the Atlantic peatlands. Species typically associated with hummocks, such as S. fuscum, Vaccinium oxycoccos, Pohlia nutans and Mylia anomala dominated the negative end of the figure. Conversely, the hollow/lawn Sphagnum fallax and S. russowii species had the highest positive scores, in conjunction with the wetland herbs Carex spp. and Eriophorum angustifolium. The trajectory of the peatland was to become slightly more forested and to be more dominated by hummockspecies (Fig. 4c).

\section{New organic matter accumulation}

The organic matter layer was $13 \mathrm{~cm}$ thick on average, but could vary notably among trenches (range 0-35 cm) and peatland regions, with Inland peatland thickness doubling that found in Lowland peatlands (Mean, Table 2). Organic matter tended to accumulate more in open systems (Best function, Table 2). However, the hummock-hollow and drywet gradients did not contribute to explain organic matter accumulation in any of the peatland regions.

Table 2. New organic matter accumulated in the three abandoned peatland regions in 20052006 as a function of their position along the ecological gradients given by the partial tbPCA ordinations

\begin{tabular}{|c|c|c|c|c|c|c|c|}
\hline & $\begin{array}{l}\text { Mean } \pm \\
\text { SE }(\mathrm{cm})\end{array}$ & PC axis & Succession gradient & Best function & $\overline{A d j} R^{2}$ & $F$ & $P$ \\
\hline Atlantic & $16 \pm 2$ & $\begin{array}{l}\mathrm{PC} 1 \\
\mathrm{PC} 2\end{array}$ & $\begin{array}{l}\text { Hummock-hollow } \\
\text { Wet-dry }\end{array}$ & Organic matter $=16($ mean $)$ & - & - & - \\
\hline Lowland & $10 \pm 1$ & $\begin{array}{l}\mathrm{PC} 1 \\
\mathrm{PC} 2\end{array}$ & $\begin{array}{l}\text { Open-closed canopy } \\
\text { Closed-open } \\
\text { understory }\end{array}$ & Organic matter $=25 * \mathrm{PC} 2+11$ & 0.04 & 3.04 & 0.087 \\
\hline Inland & $21 \pm 2$ & $\begin{array}{l}\mathrm{PC} 1 \\
\mathrm{PC} 2\end{array}$ & $\begin{array}{l}\text { Open-closed canopy } \\
\text { Hummock-hollow }\end{array}$ & Organic matter $=-27 * \mathrm{PC} 1+23$ & 0.43 & 7.87 & 0.023 \\
\hline
\end{tabular}

Note: In bold, the direction of the gradient with higher organic matter accumulation. When adjusting the functions, limits for $P$ values were set up at 0.1 because a higher error type I was considered acceptable for such an exploratory analysis. 


\section{Discussion}

\section{Development of plant communities in abandoned block-cut peatlands}

The vegetation communities in the three peatland regions showed remarkable changes for the time period (10 yr.) considered in this study, despite being very short in the time scale of peatland succession. Overall, among the three peatland regions studied, the Atlantic seemed to be most clearly on a trajectory toward recovery, with a higher abundance of moss species relative to ericaceous shrubs and trees. The greater abundance of hummock species in the second survey could indicate the initiation of a hummock-hollow gradient, as it takes only 10-30 yr for a microtopography typical of bogs to develop in restored cutover bogs (Pouliot et al., 2011). However, some caution is warranted since the increased dominance of hummock species could also simply reflect a decrease in hollow species, associated with drier conditions. In fact, this second hypothesis appears more plausible, because the most representative hollow species (e.g., S. fallax, S. magellanicum and S. angustifolium) were decreasing slightly in terms of frequency and/or cover (Appendix 1). The region's other peatland (Inkerman Ferry), however, showed a tendency toward increased wetness. We know that this was the peatland more frequently inundated among the nine included in this study (field observations).

Peatlands of the Lowland region were initially colonized by tall, dense ericaceous shrubs. There, communities maintained an ericaceous dominance over time and hence were not on a trajectory toward the recovery of a Sphagnum-dominated system. The analyses also revealed an increasing dominance of the tree strata, a result in accordance with that by Pellerin and Lavoie $(2000 ; 2003)$, who reported the afforestation of undisturbed bogs and bog remnants within surfaces mined for the production of horticultural peat within our Lowland region. They suggested that this afforestation phenomenon may have been driven mainly by drainage related to agriculture and peat extraction, fire events (especially promoting Pinus banksiana) and a dry climatic period during the first part of the $20^{\text {th }}$ century in the Bas-Saint-Laurent region. Recently, González et al. (In press) have also suggested that agricultural activities may be favoring afforestation in abandoned block-cut peatlands of the same region. It thus seems very unlikely that Lowland region peatlands evolve naturally toward Sphagnumdominated systems. Moreover, the dominant tree and ericaceous species may even inhibit future Sphagnum establishment. For example, Picea mariana, one of the species that experienced a higher increase in frequency and cover (Fig. 5b, Appendix 1), is known to increase dryness by enhancing evapotranspiration (van Seters and Price, 2001). The same process has been described for Betula trees (Fay and Lavoie, 2009). Likewise, living biomass and litter produced by the increasingly dominant vascular species may limit light availability for Sphagnum (Berendse et al., 2001).

The detailed examination of the Inland peatland showed that it was also subjected to an afforestation process (PC1, Fig. 4c). However, the greater presence of trees in this case did not prevent Sphagnum establishment. As in the Shippagan peatland, a hummock-hollow successional trend was identified as well. In this case, the hypothesis that hollow species are disappearing seems more plausible than the hypothesis that a hummock-hollow microtopography could be recovered. Frequency and cover of the most representative hollow species, $S$. fallax, decreased dramatically from the first to the second survey (Appendix 1), while other hollow/lawn species remained stable (e.g., 
S. magellanicum, Appendix 1) or increased only slightly (e.g., S. angustifolium, Appendix 1).

\section{Understanding succession to reach Sphagnum-dominated systems}

It is widely agreed that hydrological conditions (i.e., water table depths and fluctuations, and peat water content) as well as the quality and depth of the peat remaining after exploitation play a critical role in the establishment and succession of plant communities in peatlands, including block-cut sites (Rochefort and Lode, 2006). To verify this, canonical analyses for all peatland regions altogether and separately were carried out with the species cover as matrix $\mathrm{Y}$ and the peat, hydrology and landscape descriptors of Table 1 as matrix $\mathrm{X}$, but models could only explain a marginal proportion of the variability and therefore are not shown. Lack of replication for the Inland region and the only two peatlands surveyed in the Atlantic region limited the explanatory power of our predictors, especially the landscape variables, which did not differ much between trenches of the same peatland. On the other hand, environmental parameters such as those related to hydrology are hard to be characterized precisely in such an extensive study and our data were probably too restricted in time and space to allow a comprehensive understanding of factors controlling secondary succession. In addition, we think that the range of environmental variation within peat properties was too narrow to explain such similar trajectories. Nevertheless, our study only aimed at identifying general revegetation patterns to optimize the choice of restoration sites and not at disentangling the drivers of spontaneous recolonization. Studies at finer spatial scales are more appropriate in that case (e.g., microtopography scale, Tuittila et al., 2000; Pouliot et al., 2012; paleoecological analyses, Robert et al., 1999; Pellerin and Lavoie, 2000; 2003). With this limitation in mind, however, one point related to possible drivers of recolonization deserved to be mentioned. Given that the development of vegetation was different between the three block-cut peatland regions but similar within the same region, we suggest that supra-regional factors (e.g., climate, landscape) were probably among the main drivers of post-abandonment succession. For example, drier conditions in Lowland peatlands compared to the other two regions could have been exacerbated by intensified drainage of agricultural lands surrounding the trenches and by deeper secondary ditches within peatlands (Table 1, González et al. in press).

Regardless of cause, the different trajectories reported here suggest criteria for the identification of sites that require active intervention to ensure the recovery of the ability to accumulate peat, a key ecological function of bogs, and to detect trends essential to biodiversity conservation. For example, the trajectory of the Lowland peatlands will contribute little to the conservation of biodiversity and peat-accumulation functions in the region, given undesired evolution toward closed understories and canopies, and the lowest OM accumulation (Table 2). Consequently, intervention is highly recommended. In fact, some restoration measures, such as the blockage of former drainage ditches, have been carried out in three of the Lowland peatlands (Isle Verte in 1993, Saint Laurent in 2000 and Cacouna in 2006), with promising results for successful restoration: reduced runoff and a raised water-table, which improve the hydrological conditions for Sphagnum recolonization, have been reported by Ketcheson and Price (2011) for Cacouna peatland. González et al. (in press) and Henstra (2012) described positive responses of rewetting on plant composition in the three restored peatlands, namely a decrease in the dominance by trees and ericaceous shrubs, in parallel with an increase in the occurrence of hollow Sphagnum species. The Inland and, 
especially the Atlantic region peatlands are, however, on a better trajectory of recovery and intervention does not seem critical. There, future studies are needed to document long-term evolution of the transition from hollow to hummock species we observed, as well as the impact on peat accumulation.

Acknowledgements. Financial support was provided by the Natural Sciences and Engineering Research Council of Canada, the Department of Natural Resources of New Brunswick, the Canadian Sphagnum Peat Moss Association and its members. We thank Stéphanie Boudreau and Sandrine Hogue-Hugron for databank management. Thanks also to the numerous students who assisted in the field surveys and laboratory data management.

\section{REFERENCES}

[1] Andersen, R., Rochefort, L., Landry, J. (2011): La chimie des tourbières du Québec: une synthèse de 30 années de données. - Le Naturaliste Canadien 131: 5-14.

[2] Berendse, F., Van Breemen, N., Rydin, H., Buttler, A., Heijmans, M., Hoosbeek, M.R., Lee, J.A., Mitchell, E., Saarinen, T., Vasander, H., Wallen, B. (2001): Raised atmospheric $\mathrm{CO} 2$ levels and increased $\mathrm{N}$ deposition cause shifts in plant species composition and production in Sphagnum bogs. - Global Change Biology 7: 591-598.

[3] Bonham, C.D. (1989): Measurements for terrestrial vegetation. - JohnWiley and Sons, New York.

[4] Campbell, D.R., Lavoie, C., Rochefort, L. (2002): Wind erosion and surface stability in abandoned milled peatlands. - Canadian Journal of Soil Science 82: 85-95.

[5] Campbell, D.R., Rochefort, L. (2001): La végétation: gradients. - In: Écologie des tourbières du Québec-Labrador. Payette, S., Rochefort, L. (ed.) Les Presses de l'Université Laval, Québec, CA. pp. 129-140.

[6] Delage, V., Fortin, M.J., Desrochers, A. (2000): Effets de lisière et d'isolement des habitats d'oiseaux chanteurs dans les tourbières exploitées. - Écoscience 7: 149-156.

[7] Dray, S., Dufour, A.B. (2007): The ade4 package: implementing the duality diagram for ecologists. - Journal of Statistical Software 22: 1-20.

[8] Dufour, S., Piégay, H. (2009): From the myth of a lost paradise to targeted river restoration: forget natural references and focus on human benefits. - River Research and Applications 25: 568-581.

[9] Environment Canada (2012): Past Wheather. - www.ec.gc.ca.

[10] Fay, E., Lavoie, C. (2009): The impact of birch seedlings on evapotranspiration from a mined peatland: an experimental study in southern Québec. - Mires and Peat 5: 1-7.

[11] Girard, M., Lavoie, C., Thériault, M. (2002): The regeneration of a highly disturbed ecosystem: A mined peatland in southern Québec. - Ecosystems 5: 274-288.

[12] González, E., Henstra, S.W., Rochefort, L., Bradfield, G.E., Poulin, M. (2013): Is rewetting enough to recover Sphagnum and associated peat-accumulating species in traditionally exploited bogs? - Wetlands Ecology and Management (In press).

[13] Groeneveld, E., Rochefort, L. (2002): Nursing plants in peatland restoration: on their potential use to alleviate frost heaving problems. - Suo 53: 73-85.

[14] Henstra, S.W. (2012): Vegetation responses to ecological restoration (rewetting) of abandoned block-cut peatlands in Eastern Québec. - MsC Thesis. University of Waterloo. $87 \mathrm{pp}$.

[15] Hobbs, R.J., Hallett, L.M., Ehrlich, P.R., Mooney, H.A. (2011): Intervention Ecology: Applying Ecological Science in the Twenty-first Century. - BioScience 61: 442-450.

[16] Ketchenson, S.J., Price, J.S. (2011): The impact of peatland restoration on the site hydrology of an abandoned block-cut bog. - Wetlands 31: 1263-1274. 
[17] Konvalinkova, P., Prach, K. (2010): Spontaneous succession of vegetation in mined peatlands: a multi-site study. - Preslia 82: 423-435.

[18] Lavoie, C., Grosvernier, P., Girard, M., Marcoux, K. (2003): Spontaneous revegetation of mined peatlands: a useful restoration tool? - Wetlands Ecology and Management 11: $97-$ 107.

[19] Lavoie, C., Rochefort, L. (1996): The natural revegetation of a harvested peatland in southern Quebec: A spatial and dendroecological analysis. - Ecoscience 3: 101-111.

[20] Legendre, P., Gallagher, E.D. (2001): Ecologically meaningful transformations for ordination of species data. - Oecologia 129: 271-280.

[21] Legendre, P., Legendre, L. (2012): Numerical ecology, Third English edition. - Elsevier Science, Amsterdam.

[22] National Wetlands Working Group. (1988): Wetlands of Canada. - Sustainable Development Branch, Environment Canada, Ottawa, and Polyscience Publications Inc., Montréal. Ecological Land Classification Series No. 24.

[23] Oksanen, J., Guillaume Blanchet, F., Kindt, R., Legendre, P., Minchin, P.R., O'Hara, R.B., Simpson, G.L., Solymos, P., Henry, M., Stevens, H., Wagner, H. (2011): vegan: Community Ecology Package. $-\mathrm{R}$ package version 2.0-2. http://CRAN.Rproject.org/package $=$ vegan

[24] Pellerin, S., Lavoie, C. (2000): Peatland fragments of southern Quebec: recent evolution of their vegetation structure. - Canadian Journal of Botany 78: 255-265.

[25] Pellerin, S., Lavoie, C. (2003): Reconstructing the recent dynamics of mires using a multitechnique approach. - Journal of Ecology 91: 1008-1021.

[26] Poulin, M., Rochefort, L., Desrochers, A. (1999): Conservation of bog plant species assemblages: assessing the role of natural remnants in mined sites. - Applied Vegetation Science 2: 169-180.

[27] Poulin, M., Rochefort, L., Pellerin, S., Thibault, J. (2004): Threats and protection for peatlands in Eastern Canada. - Géocarrefour 79: 331-344.

[28] Poulin, M., Rochefort, L., Quinty, F., Lavoie, C. (2005): Spontaneous revegetation of mined peatlands in eastern Canada. - Canadian Journal of Botany 83: 539-557.

[29] Pouliot, R., Rochefort, L., Karofeld, E. (2011): Initiation of microtopography in revegetated cutover peatlands. - Applied Vegetation Science 14: 158-171.

[30] Pouliot, R., Rochefort, L., Karofeld, E. (2012): Initiation of microtopography in revegetated cutover peatlands: evolution of plant species composition. - Applied Vegetation Science 15: 369-382.

[31] Prach, K., Hobbs, R.J. (2008): Spontaneous succession versus technical reclamation in the restoration of disturbed sites. - Restoration Ecology 16: 363-366.

[32] Price, J.S. (2001): L'hydrologie. - In: Écologie des tourbières du Québec-Labrador. S. Payette, S., Rochefort, L. (ed.) Les Presses de l'Université Laval, Québec, CA. pp. 141158.

[33] Price, J.S., Heathwaite, A.L., Baird, A.J. (2003): Hydrological processes in abandoned and restored peatlands: An overview of management approaches. - Wetlands Ecology and Management 11: 65-83.

[34] Price, J.S., Whitehead, G.S. (2001): Developing hydrologic thresholds for Sphagnum recolonization on an abandoned cutover bog. - Wetlands 21: 32-40.

[35] Price, J.S., Whitehead, G.S. (2004): The influence of past and present hydrological conditions on Sphagnum recolonization and succession in a block-cut bog, Québec. Hydrological Processes 18: 315-328.

[36] R Development Core Team (2011): R: A language and environment for statistical computing. - R Foundation for Statistical Computing, Vienna, Austria. ISBN 3-90005107-0, URL http://www.R-project.org/.

[37] Risi, J., Brunette, C.E., Spence, D., Girard, H. (1953): Étude chimique des tourbes du Québec. - Québec Service des laboratoires, Ministère des Mines du Québec. 
[38] Robert, E.C., Rochefort, L., Garneau, M. (1999): Natural revegetation of two block-cut mined peatlands in eastern Canada. - Canadian Journal of Botany 77: 447-459.

[39] Rochefort, L. (2000): Sphagnum - A keystone genus in habitat restoration. - The Bryologist 103: 503-508.

[40] Rochefort, L. (2001): Restauration écologique. - In: Écologie des tourbières du QuébecLabrador. Payette, S, Rochefort, L. (ed.) Les Presses de l'Université Laval, Québec, CA. pp. 449-504.

[41] Rochefort, L., Isselin-Nondedeu, F., Poulin, M., Boudreau, S. (In press): Plant monitoring of an industrial peatlands under restoration: comparing survey methods for tracking 8 years of vegetation changes. - Wetlands Ecology and Management.

[42] Rochefort, L., Lode, E. (2006): Restoration of degraded boreal peatlands. - In: Boreal peatland ecosystems. Wieder, R.K., Vitt, D.H. (ed.) Springer-Verlag, Berlin, DE. pp. 924.

[43] Rochefort, L., Quinty, F., Campeau, S., Johnson, K., Malterer, T. (2003): North American approach to the restoration of Sphagnum dominated peatlands. - Wetlands Ecology and Management 11: 3-20.

[44] Rowlands, R.G., Feehan, J. (2000): The ecological future of industrially milled cutaway peatlands in Ireland. - Aspects of Applied Biology 58: 263-270.

[45] Sjörs, H. (1952): On the relation between vegetation and electrolytes in north Swedish mire waters. - Oikos 2: 241-258.

[46] Smart, P.J., Wheeler, B.D., Willis, A.J. (1989): Revegetation of peat excavations in a derelict raised bog. - New Phytologist 111: 733-748.

[47] Soro, A., Sundberg, S., Rydin, H. (1999): Species diversity, niche metrics and species associations in harvested and undisturbed bogs. - Journal of Vegetation Science 10: 549560.

[48] Tuittila, E.S., Rita, H., Vasander, H., Laine, J. (2000): Vegetation patterns around Eriophorum vaginatum L. tussocks in a cut-away peatland in southern Finland. Canadian Journal of Botany 78: 47-58.

[49] Van Seters, T.E., Price, J.S. (2001): The impact of peat harvesting and natural regeneration on the water balance of an abandoned cutover bog, Québec. - Hydrological Processes 15: 233-248.

[50] Walker, L.R., Walker, J., del Moral, R. (2007): Forging a new alliance between succession and restoration. - In: Linking restoration and ecological succession. Walker, L.R., Walker, J., Hobbs, R.J. (ed.) New York, Springer, pp. 1-18.

[51] Warner, B.G., Buteau, P. (2002): The early peat industry in Canada, 1864-1945. Geoscience Canada 27: 57-66.

[52] Warnes, G.R. Includes R source code and/or documentation contributed by: Bolker, B., Bonebakker, L., Gentleman, R.,Huber, W., Liaw, A., Lumley, T., Maechler, M., Magnusson, A., Moeller, S., Schwartz, M., and Venables, B. (2011): Gplots: Various R programming tools for plotting data. - $\mathrm{R}$ package version 2.10.1. http://CRAN.Rproject.org/package $=$ gplots 
Appendix 1. List of species identified in the three peatland regions during the two surveys $\left(1^{\text {st }}\right.$ survey $=25$ yr after abandonment, $2^{\text {nd }}$ survey $=35 y r$ after abandonment) and classified by vegetation strata. Freq. is the "species frequency" (i.e., the proportion of trenches where the species appeared). Cover is the "species cover" (i.e., mean percentage of counts within the trenches where the species was present)

\begin{tabular}{|c|c|c|c|c|c|c|c|c|c|c|c|c|c|}
\hline \multirow{24}{*}{ 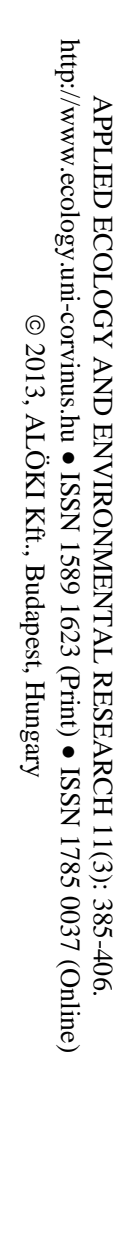 } & \multirow{3}{*}{ Species name } & \multicolumn{4}{|c|}{ Atlantic } & \multicolumn{4}{|c|}{ Lowland } & \multicolumn{4}{|c|}{ Inland } \\
\hline & & \multicolumn{2}{|c|}{$1^{\text {st }}$ survey } & \multicolumn{2}{|c|}{$2^{\text {nd }}$ survey } & \multicolumn{2}{|c|}{$1^{\text {st }}$ survey } & \multicolumn{2}{|c|}{$2^{\text {nd }}$ survey } & \multicolumn{2}{|c|}{$1^{\text {st }}$ survey } & \multicolumn{2}{|c|}{$2^{\text {nd }}$ survey } \\
\hline & & Freq. & Cover & Freq. & Cover & Freq. & Cover & Freq. & Cover & Freq. & Cover & Freq. & Cover \\
\hline & Sphagnum & & & & & & & & & & & & \\
\hline & Section Acutifolia & & & & & & & & & & & & \\
\hline & $\begin{array}{l}\text { Sphagnum fimbriatum Wils. in Wils. \& Hook. f. in Hook. } \\
\text { f. }\end{array}$ & 7 & 2 & 7 & 1 & 18 & 2 & 5 & 3 & 40 & 1 & 0 & - \\
\hline & Sphagnum flavicomans (Cardot) Warnst. & 13 & 4 & 47 & 4 & 0 & - & 0 & - & 0 & - & 0 & - \\
\hline & Sphagnum fuscum (Schimp.) Klinggr. & 80 & 8 & 100 & 11 & 40 & 2 & 35 & 4 & 100 & 21 & 100 & 30 \\
\hline & Sphagnum girgensohnii Russ. & 0 & - & 0 & - & 4 & 1 & 18 & 6 & 20 & 2 & 60 & 14 \\
\hline & $\begin{array}{l}\text { Sphagnum rubellum Wils. (Sphagnum capillifolium } \\
\text { sensu lato) }\end{array}$ & 100 & 22 & 100 & 29 & 93 & 11 & 96 & 15 & 100 & 49 & 100 & 41 \\
\hline & Sphagnum russowii Warnst. & 13 & 2 & 0 & - & 35 & 3 & 5 & 1 & 90 & 7 & 0 & - \\
\hline & Section Cuspidata & & & & & & & & & & & & \\
\hline & $\begin{array}{l}\text { Sphagnum angustifolium (C. Jens. ex Russ.) C. Jens. in } \\
\text { Tolf }\end{array}$ & 80 & 3 & 33 & 4 & 15 & 2 & 45 & 6 & 30 & 5 & 90 & 4 \\
\hline & Sphagnum cuspidatum Ehrh. ex Hoffm. & 7 & 3 & 13 & 2 & 18 & 2 & 7 & 1 & 10 & 1 & 10 & 1 \\
\hline & Sphagnum fallax (Klinggr.) Klinggr. & 47 & 7 & 20 & 2 & 51 & 5 & 22 & 3 & 80 & 7 & 0 & - \\
\hline & Sphagnum lindbergii Schimp. in Lindb. & 0 & - & 0 & - & 2 & 1 & 4 & 1 & 10 & 2 & 0 & - \\
\hline & Sphagnum majus (Russ.) C. Jens. & 0 & - & 13 & 2 & 2 & 1 & 2 & 1 & 0 & - & 0 & - \\
\hline & Sphagnum pulchrum (Lindb. ex Braithw.) Warnst. & 0 & - & 0 & - & 11 & 8 & 0 & - & 10 & 1 & 0 & - \\
\hline & Sphagnum riparium Angstr. & 0 & - & 0 & - & 9 & 3 & 2 & 1 & 30 & 2 & 0 & - \\
\hline & Section Sphagnum & & & & & & & & & & & & \\
\hline & Sphagnum magellanicum Brid. & 100 & 13 & 100 & 12 & 42 & 3 & 53 & 4 & 100 & 14 & 100 & 15 \\
\hline & Sphagnum papillosum Lindb. & 0 & - & 20 & 8 & 5 & 1 & 2 & 2 & 10 & 2 & 0 & - \\
\hline & Section Squarrosa & & & & & & & & & & & & \\
\hline & $\begin{array}{l}\text { Sphagnum squarrosum Crome } \\
\text { Bryophytes other than Sphagnum }\end{array}$ & 0 & - & 0 & - & 0 & - & 2 & 1 & 0 & - & 0 & - \\
\hline
\end{tabular}




\begin{tabular}{|c|c|c|c|c|c|c|c|c|c|c|c|c|c|}
\hline & \multirow{3}{*}{ Species name } & \multicolumn{4}{|c|}{ Atlantic } & \multicolumn{4}{|c|}{ Lowland } & \multicolumn{4}{|c|}{ Inland } \\
\hline & & \multicolumn{2}{|c|}{$1^{\text {st }}$ survey } & \multicolumn{2}{|c|}{$2^{\text {nd }}$ survey } & \multicolumn{2}{|c|}{$1^{\text {st }}$ survey } & \multicolumn{2}{|c|}{$2^{\text {nd }}$ survey } & \multicolumn{2}{|c|}{$1^{\text {st }}$ survey } & \multicolumn{2}{|c|}{$2^{\text {nd }}$ survey } \\
\hline \multirow{30}{*}{ 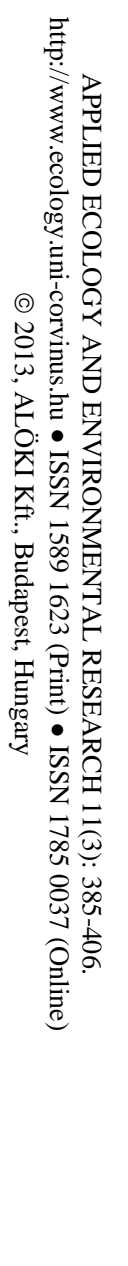 } & & Freq. & Cover & Freq. & Cover & Freq. & Cover & Freq. & Cover & Freq. & Cover & Freq. & Cover \\
\hline & Aulacomnium palustre (Hedw.) Schwaegr. & 0 & - & 0 & - & 2 & 1 & 2 & 1 & 0 & - & 0 & - \\
\hline & Calliergon stramineum (Brid.) Kindb. & 0 & - & 7 & 1 & 0 & - & 0 & - & 0 & - & 0 & - \\
\hline & Dicranella cerviculata (Hedw.) Schimp. & 7 & 1 & 0 & - & 0 & - & 0 & - & 10 & 1 & 0 & - \\
\hline & Dicranum montanum Hedw. & 0 & - & 0 & - & 2 & 1 & 0 & - & 0 & - & 0 & - \\
\hline & Dicranum polysetum $\underline{\underline{S w}}$. & 20 & 1 & 7 & 2 & 20 & 1 & 33 & 4 & 30 & 1 & 30 & 2 \\
\hline & Dicranum spadiceum J.E. Zetterst. & 0 & - & 7 & 1 & 0 & - & 0 & - & 0 & - & 0 & - \\
\hline & Dicranum undulatum Ehrh. ex Web. \& Mohr non Brid. & 7 & 1 & 27 & 1 & 18 & 2 & 53 & 3 & 0 & - & 50 & 2 \\
\hline & Drepanocladus species & 0 & - & 0 & - & 0 & - & 0 & - & 10 & 1 & 0 & - \\
\hline & Gymnocolea inflata (Huds.) Dumort. & 0 & - & 13 & 5 & 0 & - & 0 & - & 0 & - & 0 & - \\
\hline & Mylia anomala (Hook.) S. Gray & 87 & 9 & 87 & 9 & 82 & 6 & 44 & 6 & 40 & 4 & 80 & 4 \\
\hline & Plagiothecium laetum Schimp. in B.S.G. & 0 & - & 0 & - & 0 & - & 2 & 1 & 0 & - & 10 & 2 \\
\hline & Pleurozium schreberi (Brid.) Mitt. & 0 & - & 20 & 1 & 53 & 3 & 87 & 8 & 90 & 4 & 80 & 10 \\
\hline & Pohlia nutans (Hedw.) Lindb. & 7 & 1 & 0 & - & 15 & 2 & 22 & 3 & 30 & 2 & 90 & 6 \\
\hline & Polytrichum commune $\underline{\mathrm{Hedw}}$. & 0 & - & 0 & - & 0 & - & 2 & 1 & 0 & - & 0 & - \\
\hline & Polytrichum juniperinum Hedw. & 0 & - & 0 & - & 0 & - & 2 & 1 & 0 & - & 0 & - \\
\hline & Polytrichum strictum Brid. & 67 & 3 & 60 & 4 & 85 & 7 & 69 & 6 & 100 & 25 & 100 & 26 \\
\hline & Ptilidium ciliare $($ Hedw.) Lindb. & 0 & - & 13 & 12 & 7 & 1 & 45 & 3 & 0 & - & 30 & 2 \\
\hline & Ptilium crista-castrensis (Hedw.) De Not. & 0 & - & 0 & - & 0 & - & 2 & 2 & 0 & - & 0 & - \\
\hline & Ptilidium pulcherrimum $\underline{(\text { G. Web.) Hampe }}$ & 0 & - & 0 & - & 0 & - & 5 & 1 & 0 & - & 0 & - \\
\hline & Sanionia uncinata var. uncinata (Hedw.) Loeske & 0 & - & 0 & - & 0 & - & 0 & - & 10 & 1 & 0 & - \\
\hline & Steerecleus serrulatus (Hedw.) H. Rob. & 0 & - & 0 & - & 2 & 2 & 0 & - & 0 & - & 0 & - \\
\hline & Tetraphis pellucida Hedw. & 0 & - & 0 & - & 7 & 1 & 2 & 1 & 10 & 1 & 0 & - \\
\hline & $\begin{array}{l}\text { Warnstorfia exannulata (Schimp. in B.S.G.) Loeske var. } \\
\text { exannulata }\end{array}$ & 7 & 3 & 7 & 1 & 2 & 1 & 2 & 3 & 0 & - & 30 & 1 \\
\hline & Warnstorfia fluitans (Hedw.) Loeske & 7 & 1 & 0 & - & 7 & 1 & 5 & 3 & 20 & 2 & 10 & 1 \\
\hline & Lichens & & & & & & & & & & & & \\
\hline & Cladina mitis (Sandst.) Hustich & 40 & 4 & 47 & 2 & 25 & 1 & 55 & 6 & 10 & 1 & 0 & - \\
\hline & Cladina rangiferina (L.) Nyl. & 73 & 7 & 87 & 8 & 56 & 4 & 49 & 6 & 30 & 1 & 40 & 2 \\
\hline & Cladonia species & 93 & 13 & 80 & 9 & 69 & 3 & 53 & 6 & 40 & 1 & 30 & 1 \\
\hline & Herbs & & & & & & & & & & & & \\
\hline
\end{tabular}




\begin{tabular}{|c|c|c|c|c|c|c|c|c|c|c|c|c|c|}
\hline & \multirow{3}{*}{ Species name } & \multicolumn{4}{|c|}{ Atlantic } & \multicolumn{4}{|c|}{ Lowland } & \multicolumn{4}{|c|}{ Inland } \\
\hline & & \multicolumn{2}{|c|}{$1^{\text {st }}$ Survey } & \multicolumn{2}{|c|}{$2^{\text {nd }}$ survey } & \multicolumn{2}{|c|}{$1^{\text {st }}$ survey } & \multicolumn{2}{|c|}{$2^{\text {nd }}$ survey } & \multicolumn{2}{|c|}{$1^{\text {st }}$ survey } & \multicolumn{2}{|c|}{$2^{\text {nd }}$ survey } \\
\hline & & Freq. & Cover & Freq. & Cover & Freq. & Cover & Freq. & Cover & Freq. & Cover & Freq. & Cover \\
\hline & Agrostis hyemalis (Walter) Britton, Sterns \& Poggenb & 7 & 2 & 0 & - & 0 & - & 0 & - & 0 & - & 0 & - \\
\hline & Doellingeria umbellata (Mill.) Nees & 0 & - & 0 & - & 0 & - & 0 & - & 0 & - & 10 & 1 \\
\hline 急 & Calamagrostis canadensis (Michx.) P. Beauv. & 0 & - & 0 & - & 0 & - & 0 & - & 10 & 2 & 0 & - \\
\hline 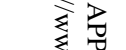 & Carex species & 33 & 6 & 0 & - & 24 & 4 & 4 & 1 & 80 & 12 & 40 & 1 \\
\hline$\underset{\pi}{\pi}$ & Geocaulon lividum (Richardson) Fernald & 0 & - & 0 & - & 0 & - & 0 & - & 0 & - & 10 & 2 \\
\hline$\delta_{0}^{0} \underbrace{\pi}_{-\pi}$ & Coptis trifolia (L.) Salisb. & 0 & - & 0 & - & 2 & 5 & 4 & 1 & 10 & 1 & 0 & - \\
\hline 高 & Cornus canadensis $\mathrm{L}$. & 0 & - & 0 & - & 20 & 4 & 13 & 4 & 10 & 1 & 0 & - \\
\hline 当。 & Cypripedium acaule Ait. & 0 & - & 13 & 2 & 5 & 1 & 4 & 1 & 0 & - & 0 & - \\
\hline (a) & Drosera intermedia Hayne & 20 & 4 & 20 & 1 & 0 & - & 0 & - & 0 & - & 0 & - \\
\hline 象象 & Drosera rotundifolia $\underline{\mathrm{L} .}$ & 80 & 3 & 87 & 5 & 31 & 2 & 11 & 15 & 10 & 1 & 90 & 2 \\
\hline $\begin{array}{ll}\omega \\
\omega\end{array}$ & Dryopteris carthusiana (Vill.) H.P. Fuchs & 0 & - & 0 & - & 2 & 2 & 0 & - & 0 & - & 0 & - \\
\hline 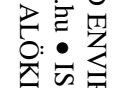 & $\begin{array}{l}\text { Eleocharis parvula (Roem. \& Schult.) Link ex Bluff, } \\
\text { Nees \& Schauer }\end{array}$ & 7 & 1 & 0 & - & 0 & - & 0 & - & 0 & - & 0 & - \\
\hline 좈윽 & Eriophorum angustifolium $\underline{\text { Honck. }}$ & 53 & 17 & 33 & 14 & 5 & 14 & 5 & 3 & 70 & 7 & 50 & 4 \\
\hline $\overrightarrow{5}$ & Eriophorum vaginatum $\mathrm{L}$. & 87 & 6 & 60 & 7 & 40 & 8 & 35 & 5 & 80 & 8 & 70 & 6 \\
\hline 罥 & Eriophorum virginicum $\underline{\mathrm{L}}$. & 13 & 1 & 40 & 3 & 4 & 11 & 0 & - & 80 & 5 & 50 & 5 \\
\hline 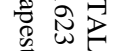 & Lycopodium annotinum $\bar{L}$ & 7 & 1 & 0 & - & 2 & 1 & 2 & 2 & 30 & 1 & 0 & - \\
\hline$\pm \pi$ & Lycopodium species other than Lyc_ann & 0 & - & 7 & 1 & 0 & - & 0 & - & 30 & 1 & 10 & 1 \\
\hline 容焉焉 & Maianthemum canadense Desf. & 0 & - & 0 & - & 4 & 2 & 0 & - & 0 & - & 0 & - \\
\hline 党 & Maianthemum trifolium (L.) Sloboda. & 13 & 5 & 13 & 6 & 0 & - & 0 & - & 0 & - & 0 & - \\
\hline 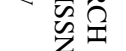 & Melampyrum lineare Desr. & 0 & - & 7 & 1 & 9 & 1 & 2 & 4 & 0 & - & 0 & - \\
\hline さこ & Osmunda cinnamomea $L$. & 7 & 1 & 0 & - & 4 & 1 & 0 & - & 0 & - & 0 & - \\
\hline 象 & Pteridium aquilinum (L.) Kuhn & 0 & - & 0 & - & 5 & 6 & 2 & 2 & 20 & 2 & 0 & - \\
\hline $8 \underset{w}{8} \underset{4}{\infty}$ & Puccinellia laurentiana Fernald \& Weath. & 7 & 9 & 0 & - & 0 & - & 0 & - & 0 & - & 0 & - \\
\hline 古 & Rhynchospora alba (L.) Vahl & 87 & 10 & 67 & 18 & 0 & - & 0 & - & 0 & - & 0 & - \\
\hline$\varrho_{ٍ}^{0}$ & Sarracenia purpurea $\underline{\mathrm{L} .}$ & 0 & - & 40 & 1 & 4 & 6 & 4 & 4 & 0 & - & 0 & - \\
\hline हैं & Scirpus microcarpus J. Presl \& C. Presl & 0 & - & 0 & - & 0 & - & 2 & 3 & 0 & - & 0 & - \\
\hline & Smilacina trifolia (L.) Desf. & 13 & 5 & 0 & - & 0 & - & 0 & - & 0 & - & 0 & - \\
\hline & Solidago rugosa Mill. & 0 & - & 0 & - & 0 & - & 0 & - & 20 & 1 & 0 & - \\
\hline & Solidago uliginosa Nutt. & 0 & - & 0 & - & 2 & 1 & 0 & - & 0 & - & 0 & - \\
\hline & Spartina alterniflora Loisel. & 7 & 1 & 0 & - & 0 & - & 0 & - & 0 & - & 0 & - \\
\hline
\end{tabular}




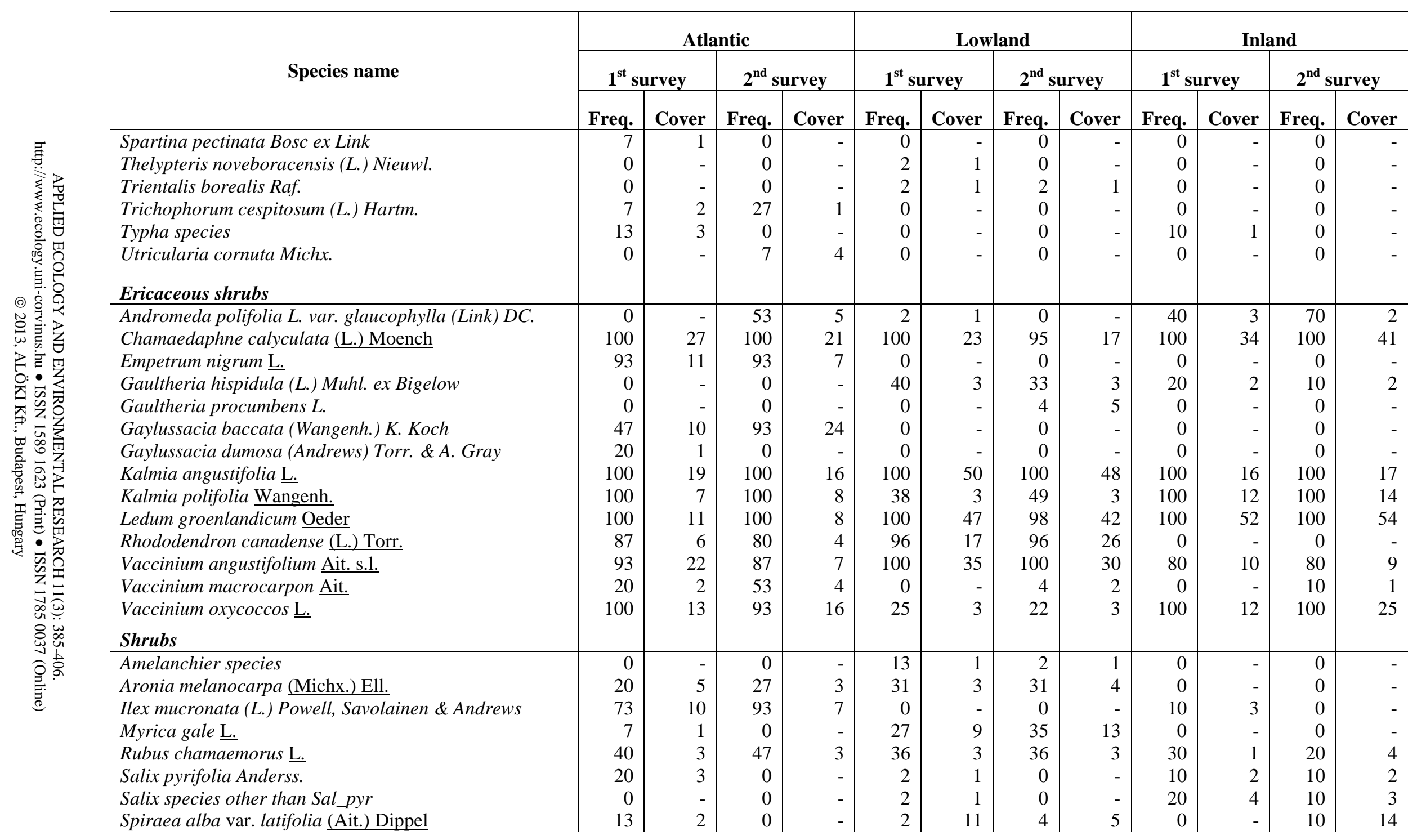




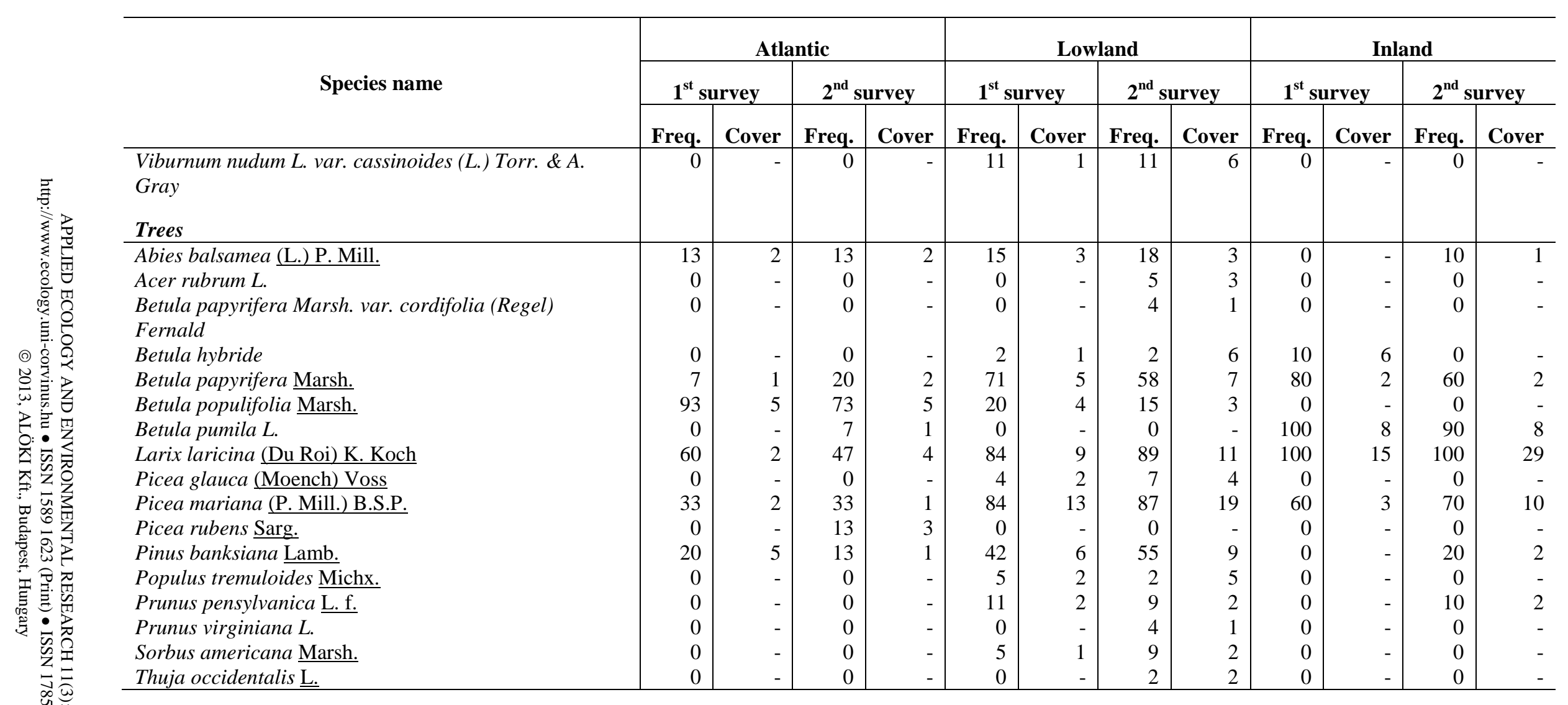

